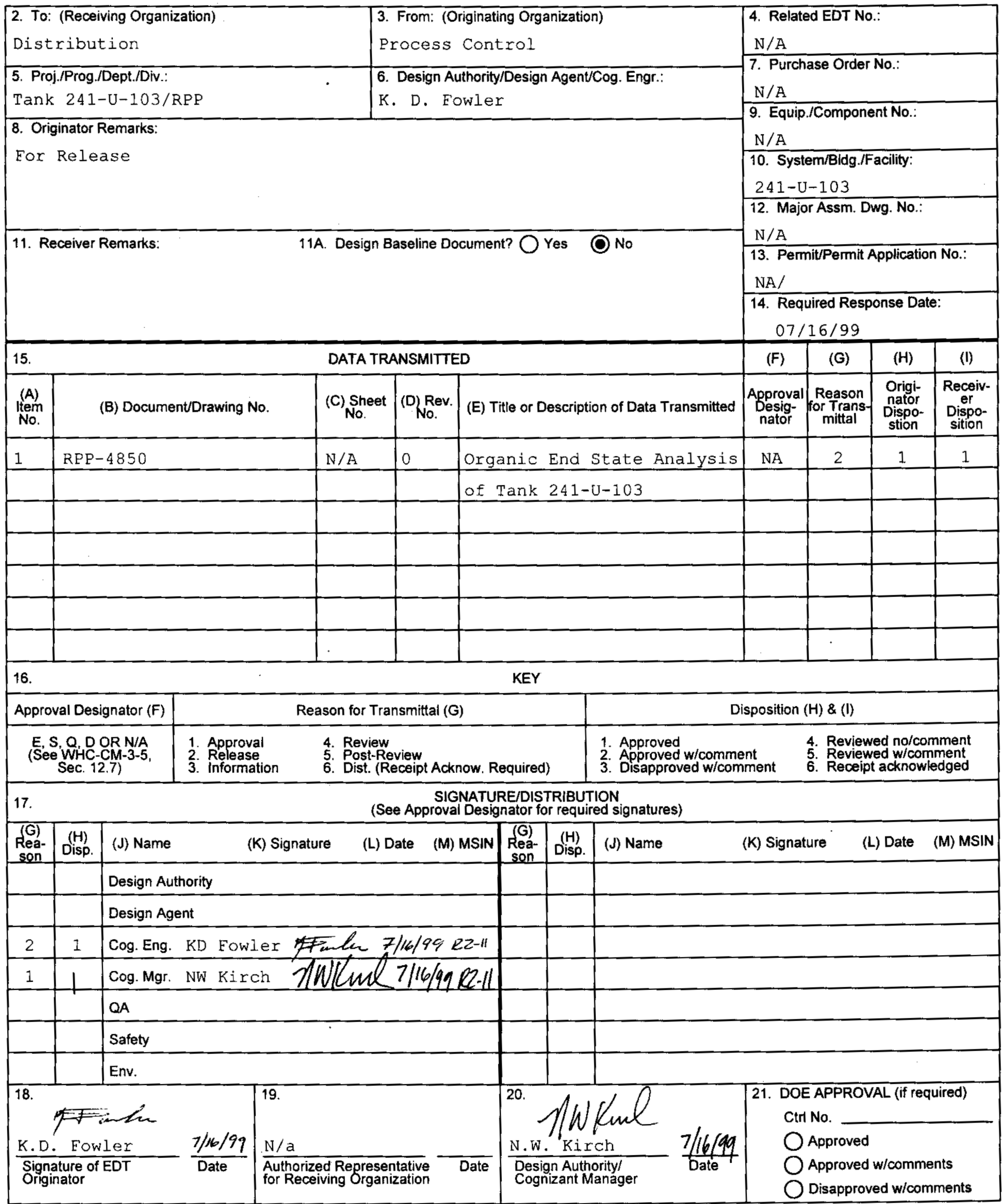




\section{Organic End State Analysis of Tank 241-U-103}

K. D. Eowler

Lockheed Martin Hanford Corp.

Richland, WA 99352

U.S. Department of Energy Contract DE-AC06-96RL13200

EDT/ECN: 626579

Org Code: $74 \mathrm{~B} 00$

UC: 2070

B\&R Code: EW 3120074

Charge Code: 108277

Total Pages: 7

Key Words: Organic, End State, Tank 241-U-103, U-103, v Farm

Abstract: N/A

TRADEMARK DISCLAMMER. Reference herein to any specific commercial product, process, or service by trade name, trademark, manufacturer, or otherwise, does not necessarily constitute or imply its endorsement, recommendation, or favoring by the United States Government or any agency thereof or its contractors or subcontractors.

Printed in the United States of America. To obtain copies of this document, contact: Document Control Services, P.O. Box 950, Mailstop H6-08, Richland WA 99352, Phone (509) 372-2420; Fax (509) 376-4989.
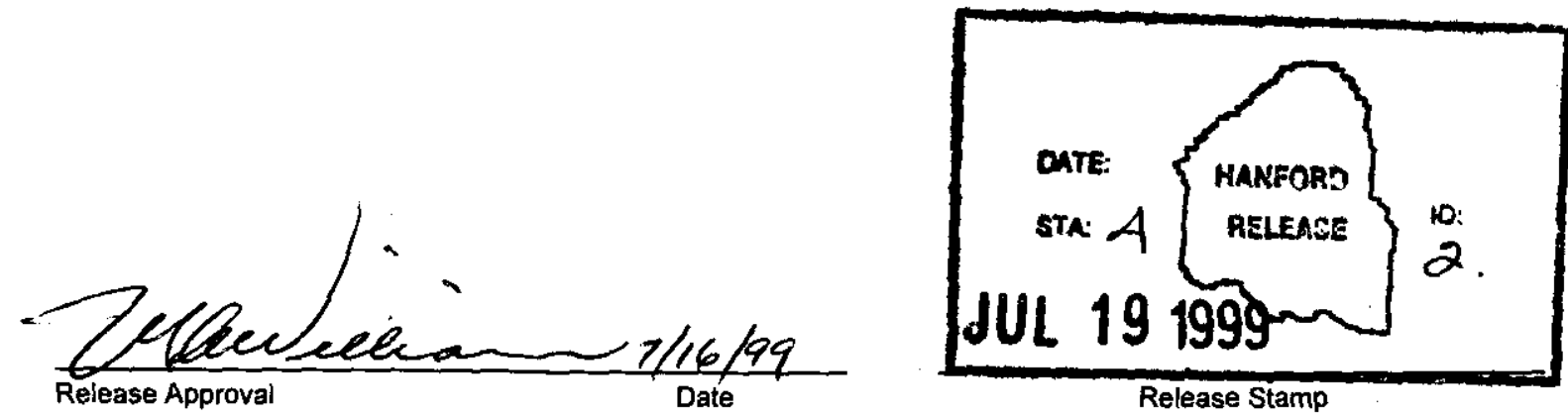

\section{Approved For Public Release}


RPP-4850, Rev. 0

\section{ORGANIC END STATE ANALYSIS OF TANK 241-U-103}

\subsection{PURPOSE}

This document provides a record of the organic end state analysis of tank 241-U-103.

\subsection{OPEN ITEMS}

There are no open items.

\subsection{DESCRIPTION OF TANK 241-U-103}

Tank 241-U-103 is one of twelve 22.9-meter (75-feet) diameter single-shell tanks in the 241-U Tank Farm in the 200 West Area of Hanford. This tank was built in 1943-1944 and has a capacity of 2,006 kiloliter (kL) (530 kilogallon [kgal]).

According to Hanlon (1999), tank 241-U-103 currently contains $1840 \mathrm{~kL}$ (468 kgal) of waste comprised of $1639 \mathrm{~kL}$ (443 kgal) saltcake, $45 \mathrm{~kL}$ (12 kgal) sludge, and $49 \mathrm{~kL}$ (13 kgal) supernatant. Included in those volumes is $867 \mathrm{~kL}(229 \mathrm{kgal})$ drainable liquid. The pumpable volume is estimated at $825 \mathrm{~kL}$ ( $218 \mathrm{kgal})$. The waste is designated as non-complexed (NCPLX). Tank 241-U-103 is a flammable gas Watch List tank. Tank 241-U-103 has not been declared as a leaker.

\subsection{METHOD OF ANALYSIS}

Analysis of tank 241-U-103 is per the methodology in HNF-SD-WM-PROC-021, Section 20.0, "End-State Organic Analysis Methodology (Single-Shell Tanks)," (Adams, 1999). Figure 1 shows the decision logic used to determine if a tank can be pumped. Information that provides the input to a decision block (criterion) is evaluated. If the preponderance of evidence (information) supports an answer of "Yes" to the decision block, pumping is allowed. If a decision block is answered "No," the logic proceeds to the next decision block and associated inputs. 
RPP-4850, Rev. 0

Figure 1. Logic To Determine Whether A Tank Can Be Pumped
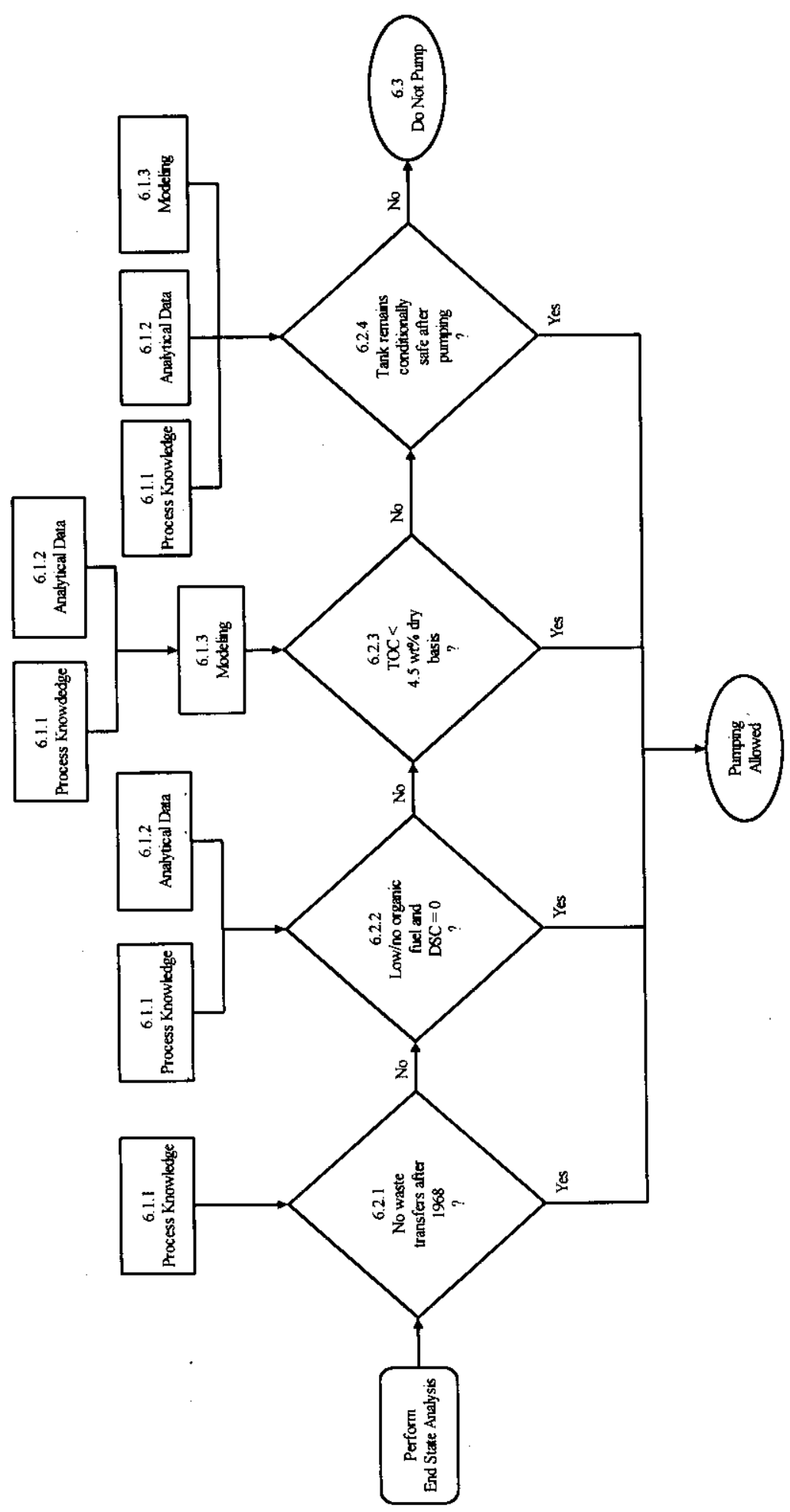
RPP-4850, Rev. 0

\subsection{RESULTS OF ANALYSIS}

Proceeding from left to right through the decision logic shown on Figure 1, a determination can be made as to whether saltwell pumping of tank $241-\mathrm{U}-103$ for interim stabilization will be allowed. The results of each step are presented in this section. The conclusion of this analysis is that tank 24l-U-103 can be pumped because the tank will not be categorized as unsafe after pumping. That determination is documented in this section.

\subsection{Criterion 6.2.1: No Waste Transfers After 1968}

Criterion 6.2.1 requires that there were no waste transfers into the tank after 1968.

Waste Transfer History

- An abbreviated description of the waste transfer history is taken from Sasaki (1998).

Tank 241-U-103 first received T Plant metal waste in February 1947. In January 1952, waste was removed to prepare the tank to receive waste from the test sluicing of tank 241-U-101. Sluicing of tank 241-U-103 for uranium recovery began in December 1952.

In the first quarter of 1957 tank 241-U-103 received metal waste and water and was filled with REDOX high-level waste supernate in 1958. Waste was removed in 1974 and the tank received flush water and evaporator bottoms through 1977. Partial neutralization feed $\left(\mathrm{HNO}_{3} / \mathrm{KMnO}_{4}\right)$ was also added to the tank in 1977.

Criterion 6.2.1 is not satisfied because waste transfers into the tank occurred after 1968. The decision logic branch requires performance of criterion 6.2 .2 .

\subsection{Criterion 6.2.2: Low/No Organic and No Exotherms}

Criterion 6.2.2 requires that the process history show the tank is expected to have no/low organic content (defined as the bulk waste possessing less than $0.53 \mathrm{wt} \% \mathrm{TOC}$ ) and that the differential scanning calorimetry (DSC) results show that there are no exotherms.

- The process history of tank 241-U-103 indicates that the waste is expected to meet the low/no organic fuel content criteria. Per Sasaki (1998), the inventory of total organic carbon (TOC) in tank $241-\mathrm{U}-103$ is estimated at $24,300 \mathrm{~kg}$. This mass of TOC is distributed through 1,771,000 liters of waste with an average density of about 1.71 . This results in a bulk TOC concentration of about $0.8 \mathrm{wt} \%$.

Additionally, tank 241-U-103 sample results reported in Sasaki (1998) showed maximum total organic carbon (TOC) contents of 2.75 and 2.33 percent dry weight for solids and drainable liquid respectively. These maximum values exceed the $0.53 \mathrm{wt} \%$ criterion.

The conditions of criterion 6.2.2 are exceeded. The decision logic branch requires performance of criterion 6.2.3. 


\subsection{Criterion 6.2.3: TOC Less Tank 4.5 Weight Percent Dry Basis}

Criterion 6.2.3 requires that an analysis of variance (ANOVA) analysis using analytical data be used to determine whether the TOC in a tank is less than the limit of $4.5 \mathrm{wt} \%$ on a dry basis at the 95 percentile with a 95 percent confidence.

- A propagation analysis for all single-shell tanks is included in Meacham, et al., 1998. Results show that propagation is not possible in tank 241-U-103 because sample data and modeling (ANOVA) show low TOC concentrations.

A tank is considered to pass the ANOVA screening if the upper $95 \%$ bound dry combustible waste fraction of the tank is below 5\%. For tank 241-U-103 the upper $95 \%$ dry combustible waste fraction is 3.4\% (Meacham, et al., 1998). Therefore, Criterion 6.2.3 is met, permitting pumping of liquid from the tank.

\subsection{CONCLUSION}

The organic end state analysis of tank 241-U-103 concludes that the tank can be pumped for interim stabilization. Saltwell pumping of the tank will not cause the waste in the tank to be categorized as unsafe. 
RPP-4850, Rev. 0

\subsection{REFERENCES}

Adams, M. R., 1999, Tank Waste Remediation System Process Engineering Instruction Manual, HNF-SD-WM-PROC-021, Rev. 2-C, Lockheed Martin Hanford Corp., Richland, Washington.

Hanlon, B. M., 1999, Waste Tank Summary Report for Month Ending April 30, 1999, HNF-EP-0182-133, Lockheed Martin Hanford Corp., Richland, Washington.

Meacham, J. E., W. L. Cowley, A. B. Webb, N. W. Kirch, J. A. Lechelt, D. A. Reynolds, L. A. Stauffer, D. B. Bechtold, D. M. Camaioni, F. Gao, R. T. Hallen, and P. G. Heasler, J. L. Huckaby, R. D. Scheele, C. S. Simmons, J. J. Toth, and L. M. Stock, 1998, Organic Complexant Topical Report, HNF-3588, Rev. 0, DE\&S Hanford, Inc., Richland, Washington.

Sasaki, L. M., 1998, Tank Characterization Report for Single-Shell Tank 241-U-103, HNF-SDWM-ER-712, Rev. 1, Lockheed Martin Hanford Corp., Richland, Washington. 
RPP-4850, Rev. 0

\section{CHECKLIST FOR DOCUMENT REVIEW}

Document Reviewed: RPP -4850 Revision: 0

Scope of Review: All - Techaical

Yes No NA

$X[][]$

$\mathbb{A}[][]$

$\mathbb{X}[][]$

[][][

$\mathrm{X}[\mathrm{]}\}]$

冈[ [ ] ]

[] []

[ ] [ ]

[] [ ] $[x]$

[] [ ] $\mathbb{X}$

[][]$\otimes$

$[\mathrm{d}][][]$

由[][]

(x] [][]

冈[ [] []

[] $\left[X^{*}\right.$
Problem completely defined.

Appropriate analytical methods used.

Necessary assumptions explicitly stated and supported.

Computer codes and data files documented.

Data used in calculations explicitly stated in document.

Data checked for consistency with original source information as applicable.

Mathematical derivations checked including dimensional consistency of results.

Models appropriate and used within range of validity or use outside range of established validity justified.

Hand calculations checked for errors. Spreadsheet results should be treated exactly the same as hand calculations.

Software input correct and consistent with document reviewed.

Software output consistent with input and with results reported in document reviewed.

Limits/criteria/guidelines applied to analysis results are appropriate and referenced. Limits/criteria/guidelines checked against references.

Safety margins consistent with good engineering practices.

Conclusions consistent with analytical results and applicable limits.

Results and conclusions address all points required in the problem statement. Review calculations, comments, and/or notes are attached.

H[ ] [ ]

Document approved.

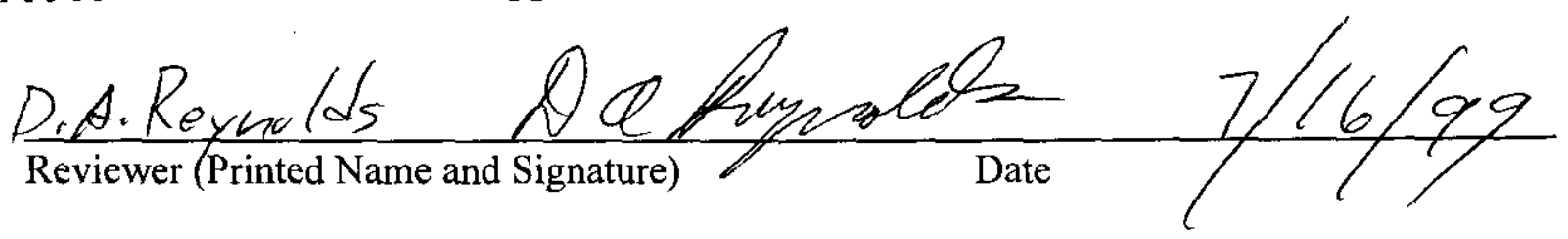

* Any calculations, comments, or notes generated as part of this review should be signed, dated and attached to this checklist. Such material should be labeled and recorded in such a manner as to be intelligible to a technically qualified third party. 


\section{DISTRIBUTION SHEET}

To

Distribution

Project Title/Work Order

RPP-4850, Rev. 0, "Organic End State Analysis of Tank 241-U-103"
From

Process Control
Page 1 of 1

Date $07 / 16 / 99$

EDT No. 626579

ECN No.

J. N. Doeler

J. G. Field

K. D. Fowler

K. M. Hall

N. W. Kirch

M. R. Koch

J. E. Meacham

D. A. Reynolds

L. M. Sasaki

D. J. Saueressig

A. B. Webb

D. T. Vladimiroff

A. E. Young

Name

Central Files

\begin{tabular}{|c|c|c|c|c|} 
MSIN & $\begin{array}{c}\text { Text } \\
\text { With All } \\
\text { Attach. }\end{array}$ & Text Only & $\begin{array}{c}\text { Attach./ } \\
\text { Appendix } \\
\text { Only }\end{array}$ & $\begin{array}{c}\text { EDT/ECN } \\
\text { Only }\end{array}$ \\
\hline
\end{tabular}

T 4-07

R2-11

R2-11

R2-12

R2-11

57 -24

R1-49

R2-11

R2-12

S7-20

$57-73$

$57-20$

$\mathrm{x}$

$\mathrm{X}$

$\mathrm{X}$

$x$

$\mathrm{x}$

$\mathrm{x}$

$x$

$\mathrm{X}$

$\mathrm{X}$

$x$

$x$

$\mathrm{X}$

\begin{tabular}{|l|}
\hline$x$ \\
\hline$x$ \\
\hline$x$ \\
\hline$x$ \\
\hline$x$ \\
\hline$x$ \\
\hline$x$ \\
\hline
\end{tabular}

R1-10

B1-07

$x$

$\mathrm{x}$

$x$

$x$

$x$

$x$

\begin{tabular}{|c|}
\hline$x$ \\
$x$ \\
\hline$x$ \\
\hline$x$ \\
\hline$x$ \\
\hline$x$ \\
\hline
\end{tabular}

$\mathrm{x}$

